\title{
EFFECT OF COLOR LIGHTS AND EXPOSURE PERIODS ON SOME BIOTECHNOLOGICAL CHARACTERS (SOLUBLE PROTEIN, SOLUBLE FATS AND PROTEIN ENZYMES) OF SILK WORM, BOMBYX MORI L.
}

\author{
A.A.A. Abdelaal, A.A. El-Dash and Samah F. Halawa \\ Economic Entomology\& Agricultural Zoology Dept. Fac. Agric. Menoufia Univ. \\ Shebin Elkom, Menuofia, Egypt.
}

Received: Aug. 15, 2018

Accepted: Oct. 10,2018

\begin{abstract}
The present study was carried out during spring season, 2017 in Sericulture Laboratory Economic Entomology Department Faculty of Agric. Menoufia Univ. The study was conducted to evaluate the effect of light color and exposure time, on some technology and physiology characters of silkworm, Bombyx mori L. Reeled silk filament characters, length $(m)$, weight $(g)$ and size (denier) were measured in the cocoons resulted from silkworm larvae exposed todifferent colors and lighting periods. The highest mean treatment length of reeled silk filament of cocoon spun by B. mori larvae exposed during the $4^{\text {th }}$ instar was $(1119.2 \mathrm{~m})$ at green light $24 \mathrm{hr}$, followed by blue light $12 \mathrm{hr}$ recording $(1077.76 \mathrm{~m})$ while green light 12hrrecorded $(954.4 \mathrm{~m}$, compared to control cocoon $(1109.76 \mathrm{~m})$. In addition, statistical analysis of the obtained results revealed that there were significant differences in the prolongation in silk filament length as compared to the control. The highest mean of reeled silk filament weight $(0.228 \mathrm{~g})$ was recorded at the cocoons spun by $B$. mori larvae exposed to green light $24 \mathrm{hr}$, followed by that exposed to red light $12 \mathrm{hr}$ recording $(0.216 \mathrm{~g})$ and blue light $12 \mathrm{hr}(0.214 \mathrm{~g})$ compared with $(0.232 \mathrm{~g})$ for control. Statistical analysis of the data indicated that there were high significant differences between lights and times in all treatments. The highest mean size of reeled silk filament $(2.08 \mathrm{dn})$ was recorded for the larvae exposed to red light $24 \mathrm{hr}$, followed by red light $12 \mathrm{hr}$ treatment giving (2.01dn), followed by (1.99 dn) at natural light treatment, and (1.96 dn) which was recorded at blue light $24 \mathrm{hr}$ treatment, compared with control which attained (1.91dn). Data regarding the biochemical analysis of total soluble protein, and protein enzymes (ALT and AST) and total fats in silk gland of silkworm larvae exposed to light and several times. The obtained results are as follow: The total soluble protein content in silk worm larvae silk gland ranged between $1.92 \mathrm{mg} / \mathrm{ml}$ for blue light $24 \mathrm{hr}, 1.88 \mathrm{mg} / \mathrm{ml}$ for red light $12 \mathrm{hr}$ and $1.87 \mathrm{mg} / \mathrm{ml}$ for green light $12 \mathrm{hr}$ compared to $1.94 \mathrm{mg} / \mathrm{ml}$ for the control larvae for silk gland samples. The total soluble protein content in silk worm larvae blood ranged between $2.68 \mathrm{mg} / \mathrm{ml}$ for green light $24 \mathrm{hr}, 2.61 \mathrm{mg} / \mathrm{ml}$ for blue light $24 \mathrm{hr}$ and $2.67 \mathrm{mg} / \mathrm{ml}$ for natural light compared to $2.45 \mathrm{mg} / \mathrm{ml}$ for the control larvae for blood samples. The total fats content of silk worm larval silk gland ranged between $139 \mathrm{mg} / \mathrm{ml}$ for natural light, $137 \mathrm{mg} / \mathrm{ml}$ for red light $24 \mathrm{hr}$ and $131 \mathrm{mg} / \mathrm{ml}$ for red light $12 \mathrm{hr}$ compared to $127 \mathrm{mg} / \mathrm{ml}$ for the control larvae for silk gland samples. The total soluble fats content in silk worm larvae blood ranged between $114 \mathrm{mg} / \mathrm{ml}$ for blue light 24 $\mathrm{hr}, 107 \mathrm{mg} / \mathrm{ml}$ for dark and $90 \mathrm{mg} / \mathrm{ml}$ for natural light compared to $98 \mathrm{mg} / \mathrm{ml}$ for the control larvae for blood samples. Silk gland activities of glutamic oxaloacetic transaminase (ALT) and Glutamic pyruvic transaminase (AST) enzymes in silk worm were measured.
\end{abstract}

Key words: Bombyx mori, Exposure periods, Color lights, Biotechnological characters. 


\section{INTRODUCTION}

The art of silk production is called sericulture that comprises cultivation of mulberry, silkworm rearing and post cocoon activities leading to production of silk yield. Sericulture provides gainful employment, economic development and improvement in the quality of life to the people in rural area and therefore it plays an important role in antipoverty program and prevents migration of rural people to urban area in search of employment. Hence several developing countries all over the world have taken up sericulture to provide employment to the people in rural areas (Walaa Nageip, 2018).

Experimental animals were reared under natural solar-day, LD 12:12 conditions at $25{ }^{\circ} \mathrm{C}$ and $80 \% \mathrm{RH}$, feeding V1 mulberry leaves. Ripening patterns in silkworm larvae initiated in the early hours of the day, LD 12:12, expressing diurnal predominance of over phenomenon, occurred in 24 hour intervals, thus expressing circadian nature and prolonged for 3 consecutive days, hence revealing gating rhythmic characteristics in all the three experimental silkworm breed/hybrid, lasting for $\mathbf{4 7}$ hours (CSR2and CSR4) to 43 hours (CSR2 $x$ CSR4). Upon application of sampoorna, the silkworm larvae did not follow circadian characteristics straightway in ripening process, expressing continuous ripening activity, lasting for 28 to 30 hours (CSR4and CSR2 respectively) and 26 hours (CSR2 x CSR4) hours (Srinath, et al., 2018b).

Conventional methods of silkworm (Bombyx mori L.) hatching include incubation, exposure to light dark cycles etc., were in practice. As a recent technology for silkworm egg hatching, use of black-boxing method coupled with incubation is advocated in the contemporary Indian sericulture industry to get economical hatching of over $95 \%$, in a single day with quick hatching. In the present study, an attempt is made to compare the photoperiodic way and the black-boxing method of hatching for better understanding the scientific principles behind the black-boxing method. For the studies, the DFLs of CSR2 $x$ CSR4 were introduced into natural solar day condition, LD 12:12, continuous dark (DD) and continuous light (LL) on the third day of oviposition and continued till the completion of hatching experiments (Srinath, et al., 2018a)

The present study was carried out during spring season of 2017 in Sericulture Laboratory, Economic Entomology Department Faculty of Agric. Menoufia University to evaluate the effect of light time and color on some technological and physiological characters of silkworm, Bombyx mori L.

\section{MATERIALS AND METHODS}

The present investigations were carried out during spring season of 2017 at Economic Entomology \& Agriculture Zoology Department Laboratory, Faculty of Agriculture, and Menoufia University.

Fresh green leaves of the mulberry variety, Morus alba native (Balady) was used and the fourth \& fifth larval instars mulberry silkworm, Bombyx mori L. $\left(H 1{ }^{*} K K^{*} G 2 * V 2\right)$ was used in the present studies. Eggs of silkworm Bombyx mori L. were purchased from the Sericulture Research Department of Plant Protection Research Institute, Agricultural Research Center, Ministry of Agriculture and Land Reclamation in Giza, Egypt.

\section{Experimental design:}

This study was carried out during spring season of 2017 in Sericulture laboratory Economic Entomology Department Faculty of Agric. Menoufia Univ. The study was conducted to evaluate the effect of color lights 
and periods of exposure on some technological and physiological characters of silkworm, Bombyx mori L., on the $4^{\text {th }}$ instar larval growth and silk production of silkworm (B. mori L.).

Three replicates, of each 100 silkworm larvae were separated for every subtreatment. Larvae of each replicate were reared on a plastic tray $(100 \times 70 \times 15 \mathrm{~cm})$ under a controlled rearing room at $27 \pm 2$ ${ }^{\circ} \mathrm{C}$ and $95 \pm 5 \% \mathrm{RH}$ for the first three instar larvae, while it was changed for the last two (Fourth and Fifth) instar to $24 \pm 2{ }^{\circ} \mathrm{C}$ and $75 \pm 5 \% \mathrm{RH}$. All the rearing room trays, racks and tools, rearing rooms as well as the rearing places were sterilized with formalin (5\%) one week before the beginning of the experiment.

\section{Larval feeding:}

Mulberry leaves were harvested four times a day, i. e. at 6 am $10 \mathrm{am}, 2 \mathrm{pm}$ and 6 pm. $4^{\text {th }}$ and $5^{\text {th }}$ larvae were offered complete leaves.

The larval bed was cleared daily, by changing net which containing rectangular holes of $0.20 \times 0.30 \mathrm{~cm}$ and quadrate holes of $1.0 \times 1.0 \mathrm{~cm}$ for the younger and the older larvae, respectively.

\section{Mounting process and fresh cocoon treatments:}

Mature larvae were transferred to carton paper (that used wrapping table eggs) for mounting process. The cocoons were harvested seven days later. Half number of the resulted cocoons of each replicate were dried in an oven (oven temperature was raised gradually until it reached $80{ }^{\circ} \mathrm{C}$ ), and then the heated cocoons were kept under maximum oven temperature degree $\left(80^{\circ} \mathrm{C}\right)$ for 6 hours. Such cocoons were used to study the technological characters. Another half of the cocoons was used for the biological studies. After emergence, each couple was impaired in a sexual paper for copulation and oviposition.

\section{Laboratory experiments:}

- The larvae were separated to nine groups:

$1^{\text {st }}$ group exposed to red light for $12 \mathrm{hrs}$ and 12 hrs dark

$2^{\text {nd }}$ group exposed to green light for 12 hrs and $12 \mathrm{hrs}$ dark

$3^{\text {rd }}$ group exposed to blue light for $12 \mathrm{hrs}$ and 12 hrs dark

$4^{\text {th }}$ group exposed to red light for $24 \mathrm{hrs}$

$5^{\text {th }}$ group exposed to green light for 24 hrs

$6^{\text {th }}$ group exposed to blue light for $24 \mathrm{hrs}$

$7^{\text {th }}$ group exposed to natural light $24 \mathrm{hrs}$

$8^{\text {th }}$ group exposed to white light 16 hrs \& 8 hrs dark

$9^{\text {th }}$ group kept in dark (away from light) 24 hrs

\section{Technological studies:}

5.1. Reelable silk filament parameters:

The weight $(\mathrm{mg})$ and length $(\mathrm{m})$ of reeled silk filament were measured and recorded. The size of the reeled filament (denier) was estimated according to (Krishna swami et al., 1972) formula:

The size of reeled filament $=$

$$
\frac{\text { weight of reeled filament }(\mathrm{mg})}{\text { Length of reeled filament }(\mathrm{m})} \times 9000
$$

\subsection{Preparation of samples for biochemical assay.}

The haemolymph was collected from a punctured proabdominal leg of the $5^{\text {th }}$ instar larvae of each treatment in glass tubes with heparin to prevent melanization of sample, Mahmoud (1988). The tubes were deep freezed at $-20^{\circ} \mathrm{C}$. The blood samples were centrifuged at $10000 \mathrm{rpm}$ for 10 minutes at $5^{\circ} \mathrm{C}$.

The supernatant was immediately assayed to determine total soluble protein and the activities of glutamic oxaloacetic transaminase (GOT), glutamic pyruvic transaminase (GPT). 


\subsection{Determination of total soluble protein.}

Colorimetric determination of total soluble protein was carried according to Gornall et al., 1949) based on the presence of an alkaline cupric sulfate, the protein produce a violet purple color, the intensity of which is proportional to their concentration. Briefly, a volume of $0.2 \mathrm{ml}$ of haemolymph was added to $5 \mathrm{ml}$ of Biuret reagent and incubated for $30 \mathrm{~min}$ at $20-25^{\circ} \mathrm{C}$. The absorbance of the sample against a blank Biuret reagent was measured at wave length of $546 \mathrm{~nm}$.

Total protein of haemolymph was estimated as $\mathrm{mg} / \mathrm{ml}$ using the formula derived from the equation of the straight line (Intercept $=0.0147$, Slop $=0.003$, Protein content $=\frac{A B S-0.0147}{0.003}$ )

Protein content $=$

$$
\frac{\text { Absorbance }- \text { Interception }}{\text { Slop }}=\mathbf{m g} / \mathbf{m l}
$$

\subsection{Determination of enzymes activities.}

-Transaminase enzymes (ALT\& AST):

Glutamic oxalo acetic transaminase (ALT) and glutamic pyruvic transaminase (AST) enzyme activities were determined colorimetriclly according to the method of Reitman and Frankle (1957). ALT transfers the amino group from Laspartate to $\alpha$-keto acid ( $\alpha$-Keto glutaric acid) producing a new amino acid (Lglutamate) and a new keto acid (oxalo acetic acid). GPT transfer the amino group from $D, L$ alanine to $\alpha$-keto acid ( $\alpha$ keto glutaric acid), resulting in a new amino acid (L-glutamate) and a new keto acid (pyruvic acid). Oxalo acetate or pyruvate reacts with 2 , 4- dinitro phenyl hedrazine forming oxaloacetate or pyruvate hydrazone which in alkaline medium form a brown colour which can measured spectro photo metrically. The reaction mixture consisted of $1 \mathrm{~m} \mathrm{I}$ of a mixture of phosphate buffer (pH 7.4) 0.2 m Ma-keto glutaric and $200 \mathrm{~m} \mathrm{M} \mathrm{-L-}$ alanine or L-aspartate, $0.2 \mathrm{ml}$ of haemolymph was then added to the reaction mixture. The mixture was incubated for $30 \mathrm{~min}$. Then after, $10 \mathrm{ml}$ of $0.4 \mathrm{~N} \mathrm{Na} \mathrm{OH}$ was added. The optical density of the produced brown colour is measured after 5 min using spectrophotometer at $520 \mathrm{~nm}$. The enzyme activity is expressed as $m M$ Pyruvatel gm body weight / min.

The glutamic oxalo acetic transaminase (ALT) and glutamic pyruvic transaminase (GPT) enzyme activities content of haemolymph samples was estimated as $\mathrm{mg} / \mathrm{ml}$ using the following formula derived from the equation of the straight line.

Intercept $=\mathbf{0 . 0 0 5 3}$, Slop $=0.0164$ (AST content $=\frac{A B S-0.0053}{0.0164}$ )

Intercept $=0.023$, Slop $=0.0019$ (ALT content $=\frac{A B S-0.023}{0.0019}$ )

AST or ALT content $=$

$$
\frac{\text { Absorbance }- \text { Interception }}{\text { Slop }}=\mathbf{m g} / \mathrm{ml}
$$

\subsection{Determination of total lipids:}

Total lipids were determined in blood of silk worm B. mori larvae and silk gland according to the method of Emile Van Handel (1985).

\section{6- Statistical analysis:}

The obtained data were subjected to statistical analysis of variance (ANOVA) at $5 \%$ probability, where the measurements were separated using Duncan's Multiple Range Test (DMRT) through CoStat software program (Version 6.400). CoStat version 6.400 Copyright (c) 1998-2008 Cohort Software. 798 Lighthouse Ave. PMB 320, Monterey, CA, 93940, USA. 


\section{RESULTS AND DISCUSSION}

1. Reeled silk filament parameters:

Reeled silk filament characters, length $(\mathrm{m})$, weight (g) and size (denier) were measured in the cocoons resulted from silkworm larvae exposed to different colors and lighting periods.

\subsection{Silk filament length $(m)$ :}

As shown in Table (1) the highest mean treatment length of reeled silk filament of cocoon spun by $B$. mori larvae exposed during the4th instar to $(1119.2 \mathrm{~m})$ at the treatment of green light $24 \mathrm{hr}$, followed by blue light $12 \mathrm{hr}$ recording $(1077.76 \mathrm{~m})$ while green light $12 \mathrm{hr}$. recorded $(954.40 \mathrm{~m})$ On the other hand, control cocoon gave $1109.76 \mathrm{~m}$. In addition, statistical analysis of the obtained results of all tested lights revealed that there were significant differences in the prolongation in silk filament length as compared to the control.

\subsection{Silk filament weight (g):}

As shown in Table (1) the highest mean of reeled silk filament weight $(0.228$ g) was recorded at the cocoons spun by B. mori larvae exposed to green light 24 $\mathrm{hr}$, followed by that of the larvae exposed to red light $12 \mathrm{hr}$ recording $(0.216 \mathrm{~g})$ and blue light $12 \mathrm{hr}$ recording (0.214 g) compared with $(0.232 \mathrm{~g})$ was recorded for control during 2017 season. Statistical analysis of the data indicated that there were high significant differences between lights and times in all treatments.

Table (1): Effect of color lights and periods of exposure on Filament length (m.), Filament weight (g.) and Filament size (dn.) of silkworm, Bombyx mori L. in 2017 season

\begin{tabular}{|c|c|c|c|c|}
\hline Time & Color & $\begin{array}{l}\text { Filament length } \\
\text { (m) }\end{array}$ & $\begin{array}{l}\text { Filament weight } \\
\text { (g) }\end{array}$ & $\begin{array}{c}\text { Filament size } \\
\text { (dn) }\end{array}$ \\
\hline \multirow{4}{*}{$12 \mathrm{~h}$} & Red & 900.160 & 0.216 & 2.010 \\
\hline & Green & 954.400 & 0.206 & 1.620 \\
\hline & Blue & 1077.76 & 0.214 & 1.820 \\
\hline & mean & 977.440 & 0.212 & 1.810 \\
\hline \multirow{4}{*}{$24 \mathrm{~h}$} & Red & 932.100 & 0.188 & 2.080 \\
\hline & Green & 1119.20 & 0.228 & 1.830 \\
\hline & Blue & 884.160 & 0.192 & 1.960 \\
\hline & mean & 978.490 & 0.203 & 1.960 \\
\hline \multicolumn{2}{|c|}{ Dark 24} & 841.600 & 0.160 & 1.720 \\
\hline \multicolumn{2}{|c|}{ Natural light } & 954.080 & 0.212 & 1.996 \\
\hline \multicolumn{2}{|c|}{ Control } & 1109.76 & 0.232 & 1.910 \\
\hline \multicolumn{2}{|c|}{ LSD. for color } & $117.0022^{\star \star \star}$ & $0.037^{*}$ & ns \\
\hline \multicolumn{2}{|c|}{ P.0.05 } & 0.0000 & 0.0115 & 0.7613 \\
\hline \multicolumn{2}{|c|}{ LSD for time } & $77.1390^{\star \star *}$ & $0.0290 * * *$ & Ns \\
\hline \multicolumn{2}{|c|}{ P 0.05} & 0.0000 & 0.0000 & 0.2022 \\
\hline
\end{tabular}




\subsection{Silk filament size (dn):}

Data presented in Table (1) indicated that the highest mean size of reeled silk filament $(2.08 \mathrm{dn})$ was recorded for the larvae exposed to red light $24 \mathrm{hr}$, followed by red light $12 \mathrm{hr}$ treatment giving $(2.01 \mathrm{dn})$, followed by $(1.99 \mathrm{dn})$ at natural light treatment, and (1.96 dn.) which was recoded at blue light $24 \mathrm{hr}$ treatment, compared with control which attained (1.91dn) Silk filament size. Statistical analysis of the data indicated that there were high significant differences between lights and times in all treatments.

The obtained results are in harmony with those of El-Shaarawy et al. (1977), El-Karaksy and Idriss (1990), Babu et al. (1992) who found that the maximum lengths of secretory glands and reservoirs and the heaviest weights of reservoirs, fresh and dry cocoon and cocoon cortex and the maximum lengths of reeled silk.

Similar results were recorded with Mubashir and Humayun (2002) and Saad (2009), Zannoon et al. (2008). Moreover, Balasundaram and Selvisabhanayakam (2009), Munghate et al. (2009) and Omer et al. (2009). Also, Saad et al. (2014) who cleared that mulberry leaves fortified with $0.5,0.1$ and $0.2 \%$ with glycine, and 0.125 , 0.25 and $0.5 \%$ with ascorbic acid for start 5th instar, indicated that there was no significant change in the body weight of the larvae of all three groups, however significantly increases in the silk filament length was recorded with 0.1 and $0.2 \%$ glycine and $0.25,0.5 \%$ ascorbic acid. Balasundaram et al. (2013) indicated that the ascorbic acid exhibits the presence of certain growth stimulant activity and can be used to increase the silk yield in commercial silkworm rearing.

2. Effect of color lights and periods on soluble protein, soluble fats and protein enzymes of Silk Worm, Bombyx mori L. in larvae blood:

Data regarding the biochemical analysis of total soluble protein, and protein enzymes (ALT and AST) and total fats in blood larvae of silkworm exposed to different lights and times in Table (2).

\subsection{Total soluble protein $(\mathrm{mg} / \mathrm{ml})$ :}

The total soluble protein content in larvae blood of silk worm was $2.68 \mathrm{mg} / \mathrm{ml}$ for green light $24 \mathrm{hr}, 2.33 \mathrm{mg} / \mathrm{ml}$ for red light $12 \mathrm{hr}$ and $2.34 \mathrm{mg} / \mathrm{ml}$ for green light $12 \mathrm{hr}$, compared to $2.45 \mathrm{mg} / \mathrm{ml}$ for the control larvae.

\subsection{Total fats $(\mathrm{mg} / \mathrm{ml})$ :}

The total soluble protein content in larvae blood of silk worm was $114 \mathrm{mg} / \mathrm{ml}$ for blue light $24 \mathrm{hr}, 107 \mathrm{mg} / \mathrm{ml}$ for dark and $90 \mathrm{mg} / \mathrm{ml}$ for natural light compared to $98 \mathrm{mg} / \mathrm{ml}$ for the control larvae of blood samples

\subsection{AST content $(\mathrm{mg} / \mathrm{ml})$ :}

The mean content of ALT enzymes ranged $703 \mathrm{mg} / \mathrm{ml}$ for red light $12 \mathrm{hr}, 519$ $\mathrm{mg} / \mathrm{ml}$ for blue light $12 \mathrm{hr}$ and $510 \mathrm{mg} / \mathrm{ml}$ for blue light $24 \mathrm{hr}$ compared to 609 $\mathrm{mg} / \mathrm{ml}$ for the control larvae of blood samples

\subsection{ALT content $(\mathrm{mg} / \mathrm{ml})$ :}

The mean content of ALT enzymes ranged $316 \mathrm{mg} / \mathrm{ml}$ for green $12 \mathrm{hr}, 284$ $\mathrm{mg} / \mathrm{ml}$ for green light $24 \mathrm{hr}$ and $274 \mathrm{mg} / \mathrm{ml}$ for red light $12 \mathrm{hr}$ compared to $302 \mathrm{mg} / \mathrm{ml}$ for the control larvae of blood samples.

3. Soluble protein \& fats and protein enzymes in silk gland larvae of $B$. mori

Results in Table (3) show the total soluble protein and protein enzymes (ALT and AST) and soluble fats $(\mathrm{mg} / \mathrm{g})$ in silk gland of Bombyx mori larvae as affected by different color lights and photo periods. 
3.1. Total soluble protein $(\mathrm{mg} / \mathrm{ml})$ :

The total soluble protein content in silk gland of larvae was $1.92 \mathrm{mg} / \mathrm{ml}$ for blue light $24 \mathrm{hr}, 1.88 \mathrm{mg} / \mathrm{ml}$ for red light
$12 \mathrm{hr}$ and $1.87 \mathrm{mg} / \mathrm{ml}$ for green light $12 \mathrm{hr}$ compared to $1.94 \mathrm{mg} / \mathrm{ml}$ for the control larvae of silk gland samples.

Table (2): Effect of color lights and periods of exposure on the biochemical analysis of total soluble protein and protein enzymes (ALT and AST) and soluble fats ( $\mathrm{mg} / \mathrm{g})$ in blood of silkworm larvae, Bombyx mori in 2017 season

\begin{tabular}{|c|c|c|c|c|c|}
\hline \multirow{3}{*}{ Time } & Color & $\begin{array}{c}\text { Soluble protein } \\
(\mathrm{mg} / \mathrm{g})\end{array}$ & $\begin{array}{c}\text { Soluble fats } \\
(\mathrm{mg} / \mathrm{g})\end{array}$ & AST & ALT \\
\hline \multirow{3}{*}{$12 \mathrm{~h}$} & Red & $2.33 \mathrm{~d}$ & $77 \mathrm{f}$ & $703 \mathrm{a}$ & $274 \mathrm{~cd}$ \\
\cline { 2 - 6 } & Green & $2.34 \mathrm{~d}$ & $85 \mathrm{def}$ & $318 \mathrm{e}$ & $316 \mathrm{a}$ \\
\cline { 2 - 6 } & Blue & $2.63 \mathrm{ab}$ & $83 \mathrm{def}$ & $519 \mathrm{c}$ & $270 \mathrm{~cd}$ \\
\hline \multirow{3}{*}{$24 \mathrm{~h}$} & Green & $2.47 \mathrm{bcd}$ & $79 \mathrm{ef}$ & $374 \mathrm{de}$ & $266 \mathrm{~d}$ \\
\cline { 2 - 6 } & Blue & $2.68 \mathrm{a}$ & $88 \mathrm{cde}$ & $318 \mathrm{e}$ & $284 \mathrm{bcd}$ \\
\hline & Dark 24 & $2.47 \mathrm{bcd}$ & $114 \mathrm{a}$ & $510 \mathrm{c}$ & $268 \mathrm{~d}$ \\
\hline & Natural light & $2.67 \mathrm{a}$ & $107 \mathrm{ab}$ & $460 \mathrm{~cd}$ & $288 \mathrm{bc}$ \\
\hline & Control & $2.45 \mathrm{~cd}$ & $90 \mathrm{~cd}$ & $216 \mathrm{f}$ & $106 \mathrm{e}$ \\
\hline LSD 5\% & & 0.17 & $98 \mathrm{bc}$ & $609 \mathrm{~b}$ & $302 \mathrm{ab}$ \\
\hline
\end{tabular}

Means in each column followed by the same letter (s) are not significantly different at $5 \%$ level.

Table (3): Effect of color lights and periods of exposure on the biochemical analysis of total soluble protein and protein enzymes (ALT and AST) and soluble fats $(\mathrm{mg} / \mathrm{g})$ in silk gland of Bombyx mori larvae in 2017 season

\begin{tabular}{|c|c|c|c|c|c|}
\hline Time & Color & $\begin{array}{c}\text { Soluble protein } \\
(\mathrm{mg} / \mathrm{g})\end{array}$ & $\begin{array}{l}\text { Soluble fats } \\
(\mathrm{mg} / \mathrm{g})\end{array}$ & ALT & AST \\
\hline \multirow{3}{*}{$12 \mathrm{~h}$} & Red & $1.88 a b$ & $131 a b$ & $713 \mathrm{c}$ & $440 \mathrm{~d}$ \\
\hline & Green & $1.87 a b$ & 119abc & $135 \mathrm{f}$ & $748 a$ \\
\hline & Blue & $2.00 \mathrm{a}$ & $128 a b$ & 255 e & $540 \mathrm{~b}$ \\
\hline \multirow{6}{*}{$24 \mathrm{~h}$} & Red & $1.73 \mathrm{~b}$ & $137 a b$ & $805 \mathrm{~b}$ & $495 \mathrm{c}$ \\
\hline & Green & $1.86 a b$ & $101 \mathrm{c}$ & $395 d$ & $494 \mathrm{c}$ \\
\hline & Blue & $1.92 \mathrm{ab}$ & $115 b c$ & $810 \mathrm{~b}$ & $420 \mathrm{~d}$ \\
\hline & Dark 24 & $1.89 a b$ & 119abc & 290 e & $384 \mathrm{e}$ \\
\hline & Natural light & $1.85 a b$ & $139 a$ & $975 a$ & $540 \mathrm{~b}$ \\
\hline & Control & $1.94 a b$ & $127 a b$ & $225 \mathrm{e}$ & $492 \mathrm{c}$ \\
\hline \multicolumn{2}{|c|}{ LSD 5\% } & 0.22 & 23.9 & 84.2 & 26.2 \\
\hline
\end{tabular}

Means in each column followed by the same letter (s) are not significantly different at $5 \%$ level. 


\subsection{Total fats $(\mathrm{mg} / \mathrm{ml})$ :}

The total fats content in silk gland of larvae was $139 \mathrm{mg} / \mathrm{ml}$ for natural light, $137 \mathrm{mg} / \mathrm{ml}$ for red light $24 \mathrm{hr}$ and 131 $\mathrm{mg} / \mathrm{ml}$ for red light $12 \mathrm{hr}$ compared to 127 $\mathrm{mg} / \mathrm{ml}$ for the control larvae of silk gland samples.

\subsection{ALT content $(\mathrm{mg} / \mathrm{ml})$ :}

The mean content of ALT enzymes ranged $975 \mathrm{mg} / \mathrm{ml}$ for natural light, 920 $\mathrm{mg} / \mathrm{ml}$ for dark and $810 \mathrm{mg} / \mathrm{ml}$ for blue light $24 \mathrm{hr}$ compared to $522 \mathrm{mg} / \mathrm{ml}$ for the control larvae for silk gland samples.

\subsection{AST content $(\mathrm{mg} / \mathrm{ml})$ :}

The mean content of AST enzymes in silk gland of larvae was $748 \mathrm{mg} / \mathrm{ml}$ for green light $12 \mathrm{hr}, 540 \mathrm{mg} / \mathrm{ml}$ for both dark and blue light $12 \mathrm{hr}$, compared to 492 $\mathrm{mg} / \mathrm{ml}$ for the control larvae of silk gland samples.

It is known that there is a high correlation between the leaf protein level and production efficiency of the cocoon shell, which means the cocoon shell weight of the total amount of mulberry leaves consumed by the silkworm Machii (1989), Machii and Katagiri (1991).

Therefore, an increase in the protein level of mulberry leaves may lead to improvement in silk productivity. The mulberry trees in Egypt, are among the poorest in terms of nutrition, due to their neglect in terms of fertilization, irrigation and agricultural practices. There are many varieties of mulberry over the world, which are characterized by high productivity of leaves as well as high protein content and mineral salts and vitamins. Mulberry is a rich source of protein, carbohydrates, carotenoids, lipids, ascorbic acid, antho cyanins. Five mulberry M5, RFs-135, V1, S36, S13 were analysed for their leaf quality through phytochemical tests. Results reviled the best one containing highest total soluble protein $(111.40 \mu \mathrm{g} / \mathrm{g})$, total free amino acid
(9.88 $\mu \mathrm{g} / \mathrm{g}$ ) and total phenol (4.96\%) content compare to other four varieties so V1 is the highly recommendable feed for silkworm (B.mori L.) to increase their silk productivity Jyothi et al. (2014) and Madhu et al. (2014).

Also, Singh et al. (1985) estimated the enzyme activities of Glutamate oxalo acetate transaminase (GOT) and Glutamate pyruvic transaminase (GPT) in the silk gland of eri-silkworm, Philosamia ricini. It was found that getting activity was higher than GPT (about twice) in the middle portion, while in the posterior silk gland, GPT activity was higher (3-4 times) than got activity.

Moreover, El-Karaksy and Idriss (1990) found that ascorbic acid at different concentrations $(0.25,0.5,1$ and $2 \%)$ lead to increase significantly the weights of both larvae and pupae.

El-Bermawy and Abdel Fattah (2000). Also, Singaravelu et al. (2004) found that oral supplementation of magnesium sulphate with different concentrations to silkworm larvae of $B$. mori L. resulted in a significant influence on the assessed economic characters. Assessment of biochemical parameters of biomolecules (protein, carbohydrate and lipid) of digestive tissues illustrate its biological effect.

Rahmathulla et al. (2007) reported that dietarysupplementation of folic acid (Vitamin B) to silkworm larvae did notsignificantly increase the glycogen content of the body, where as in haemolymph treh alose content increases significantly.

Khedr et al. (2013) in a comparative study in Egypt, using two mulberry varieties Morus albavar. Kokuso-27 and $M$. indica var. Kanva-2 were compared with $M$. albavar. Balady (native) in their effects on the protein banding patterns of 5th-instarlarvae of $B$. mori. There was an 
obvious variation in the number and position of the bands, with many bands specific to a particular treatment. Protein of larvae fed on Kokuso-27 was characterized by the presence of 29 and $10 \mathrm{KDa}$ bands; Kanva-2 produced bands at 251, 74 and $8 \mathrm{KDa}$; and Balady was characterized by bands at 38 and $11 \mathrm{KDa}$. When Kokuso-27 was enriched with vitamins C or B, or any of three kinds of bee-honey (clover, cotton and citrus honey) at various concentrations, new protein bands appeared relative to controls.

Thulasi and Sivaprasad (2013) and Thulasi et al. (2015) cleared that, highly significant elevation in the total soluble protein and increased number of protein bands, while decreased significantly the activity of transaminase enzymes (AST and ALT) either in honey or Pharovit treatments comparing to control. Though, the nutritional importance of ascorbic acid is well substantiated, the role of lemon juice needs further investigations at higher concentrations .

Moreover, Thulasi and Sivaprasad (2015) suggested that honey is a profitable supplementary diet for silkworm which reinforces the day-to-day larval growth, silk gland growth and the gland-body ratio. It stimulates silk protein synthesis in all the three segments of the silk gland. Also, Ohila and Asiya (2016) indicated that administration of vitamin C stimulate metabolic activity which is used to increase the growth and feeding efficiency with reference to silkworm rearing observed that the $0.5 \%$ vitamin $C$ treated group plays a significant role with an increase in growth and better food intake compared to control group and other vitamin $C$ treated groups.

\section{REFERENCES}

Babu, M., M. T. Swamy, P. K. Rao and M.S. Rao (1992). Effect of ascorbic acid -enriched mulberry leaves on rearing of B. mori. Indian Journal of Sericulture. 31(2):111-114.

Balasundaram, D. and Selvisabhanayakam (2009). Effect of vitamin $C$ enrichment on economic characters of the silkworm $B$. mori. Journal of Eco-biology 24(4):395-399.

Balasundaram, D., P. Ganesh Prabu, Selvisabhanayakam, V. Mathivanan and V. Ramesh (2013). Biotechnological Applications and Nutritional Supplementation of Ascorpic Acid (Vitamin C) Treated Morus alba(L.)Leaves Fed by Silkworm, B. mori(L.) (Lepidoptera: Bombycidae) in Relation to Silk Production. International Journal of Research in Biomedicine and Biotechnology, 3(1): 11-16.

El-Bermawy, S. M. and H. M. Abdel Fattah (2000). Changes in protein in $4^{\text {th }}$ instar larvae after electrophoretic pattern of Tribolium confusum treatment with volatile plant oil (Vetiver). J. Egypt. Ger. Soc. Zool., 31, 167-182.

El-Karaksy, I. A. and M. Idriss (1990). Ascorbic acid enhances the silk yield of the mulberry silkworm, Bombyx moriL. Journal of Applied Entomology. 109(1):81-86.

EL-Shaarawy, M. F., A. A. Gomaa, Y. S. Salem and M. A. Rizk (1977). Effect of dietary constituents on the yield of silk produced by mulberry silk worm B. mori and its technological properties. Zeitschrift Fuer Angewanddte Zoologie, 64 (4): 385396.

Emile Van Handel (1985). Rapid determination of total lipids in mosquitoes. J. Aru. Mosq. Conrnol Assoc. Vou L, No.3 : 302-304.

Gornall, A.G., C.J. Bardawill and M.M. David (1949). Determination of serum protein by means of bruit reaction. $J$. Biological Cham. 177: 751-766.

Jyothi, M., M. Pratap and S.T. Naik (2014). Studies on biochemical constituents of different genotypes of Morus albaL. 
International Journal of Pharma and BioSciences ; 5(2);835-840.

Khedr, M. M. A., Samah N. El-Shafiey and Hala M. I. Mead (2013). Influence of fortification of mulberry leaves with natural and synthetic multivitamins on growth and development of $B$. mori $L$. J. Plant Prot. And Path., Mansoura Univ. 4 (1): 111 - 123.

Krishna swami Sengupta, B.D. Singh and J.C. Mustafi (1972). Nutrition of silkworm, Bombyx mori L. I. Studies on the enrichment of mulberry leaf with various sugars, proteins, amino acids and vitamins for vigorous growth of the worm and increased cocoon crop protection. Indian J. Seric. 11 (1): 1-27.

Machii, H. (1989). varietal differences of nitrogen and amino acid contents in mulberry leaves. Acta. Seric. Entomol., 1:51-61.

Machii, H. and K. Katagiri (1991). varietal differences in nutritive values of mulberry leaves for rearing silk worms. JARQ, Japan Agriculture Research Quarterly, 25(3): 202-208.

Mahmoud, S. M. (1988). Activation of silk secretion by silkworm, Philosamia ricini and Bombyx mori after applying antibiotics. Ph. D. Thesis, Faculty Agric., Cairo University, Egypt.

MadhuBabu, T., R. Seenaiah, P. Akbar Basha and S. Thimma Naik (2014). Studies on the biochemical and bioassay different varieties of mulberry (Morusalba L.) leaves fed by silkworm in relation to silk production. International Journal of Biological \& Pharmaceutical Research; 5(8):664667.

Mubasir, H. and J. Humayun (2002). effect of $0.2 \% \mathrm{~N}$ with various combinations of ascorbic acid on growth and silk production of silkworm (B. moriL.). Asian Journal of Plant Sciences. 1 (6): 650-651.

Munghate, R. S., S. M. Wankhede, P.N. Mane, M. R. Somkuwar and S. B.
Dhurve (2009). Effect of fortified mulberry leaves with ascorbic acid on growth and development of $B$. moriL. Journal of Soils and Crops Research Scientists.

Omer, R.E.M., M.M. Khattab, A.A. ElBerry, A.A.I. Zannoon and M.S.I. Saad (2009). Effect of enriching mulberry leaves with some nutritional elementson some biological and productivity characters of the mulberry silkworm, Bombyx mori L. Zagazig J. Agric. Res., Vol. 36 No. (5) 2009

Ohila, M. S. and F. B. Asiya Nuzhat (2016). Effect of Synthetic Vitamin 'C' Supplementation on Growth and Food utilization In NB4D2 race of Silkworm, B. mori L. Scholars Academic Journal of Biosciences, 4(1):27- 32.

Reitman, S. and S. Frankel (1957). Glutamic - pyruvate transaminase assay by colorimetric method. Am. J. Clin. Path 28: 56.

Saad, M. I. S. (2009). Effect of some chemical elements on mulberry silkworm, B. mori L. Ph. D. Thesis, Fac. Agric. Benha Univ., Egypt.

Saad, I. A. I., H. Rehab and M. S. I. Saad (2014). Effect of mulberry leaves enriched with the amino acid glycine on some biological aspects of silkworm, B. mori L. Minufiya J. Agri. Res. 39, 2 (2), 759-764.

Singaravelu, G., S. Anbu, P. Prabu and K. Govindaraju (2004). Effect of supplementation of micronutrient, magnesium sulphate on certain aspects of silkworm, B. mori $L$. Journal of Entomological Research, 28(3): 205- 210.

Singh, S. P., M. K. Singh and G. B. Singh (1985). Changes in the transaminase activity in the middle and posterior silk gland tissue of eri silkworm Philosamia ricini in relation to spinning process. Acta Physiol. Hung., 66(1): 61-64. 
Srinath, B., Shanthan Babu, M.A., Lakshminarayana Reddy, P., B. Sujatha and S. Sankar Naik (2018)a. Impact of phoyto ecdysone, 'sampoorna' on the synchronization of ripening in the commercial silkworm, Bombyx mori L. -a chrono biological perspective. International Journal of Science and Nature ,9 (1) : 11-16.

Srinath, B, M.A. Shanthan Babu, P. Lakshmi Narayana Reddy, B. Sujatha and S. Sankar Naik (2018)b. Hatching patterns in the silkworm, Bombyx mori L. under 'black-boxing' system: A photoperiodic perspective. International Journal of Advanced Science and Research .3(1): 152-157.

Thulasi, N. and S. Sivaprasad (2013). Synergetic effect of ascorbic acid and lemon juice on the growth and protein synthesis in the silkworm, B. mori and its influence on economic traits of sericulture. Journal of Bio Innovation; 2(4):168-183.

Thulasi, N. and S. Sivaprasad (2015). Larval growth, silk production and economic traits of $B$. mori under the influence of honey-enriched mulberry diet. Journal of Applied and Natural Science 7 (1): 286 - 292.

Thulasi, N. E., Bhuvanewari R. Madhavi and S. Sivaprasad (2015). Larval growth, silk production and economic traits of $B$. mori under the influence of Nutrilite-enriched mulberry diet. International journal of Advances in Pharmacy, Biology and Chemistry. 4(3), 2277 - 4688.

Walaa Nageip (2018). Effect of some natural products onmulberry silkworm, Bombyx mori L. M.Sc. Thesis, Fac. Sci., Zagazig Univ., Egypt. Zannoon, A. H. A. I., E. M. M. Hassan, S. S. El-Akkad, I. M. Abdel-Nabi and S. M. Zalat (2008). Biological and technological effects of mulberry varieties and nutritional additives on silkworm B. mori development. Egyptian Journal of Biology, (10):1119. 
تأثير لون الاضاءة وفترات التعرض على بعض القياسات البيوتكنولوجية (البروتينات

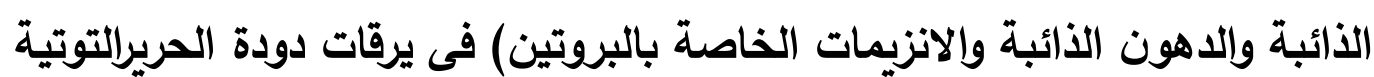

\author{
احمد عبد القوى احمد ، احمد أحمد عبد الحميد الاش ، سماح فتحى حلاوة \\ قسم الحشرات الاقتصادية والحيوان الززاعى - كلية الزراعة - جامعة المنوفية الحئ
}

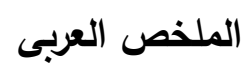

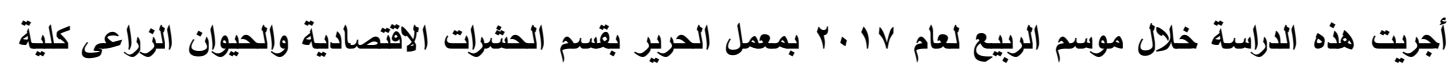

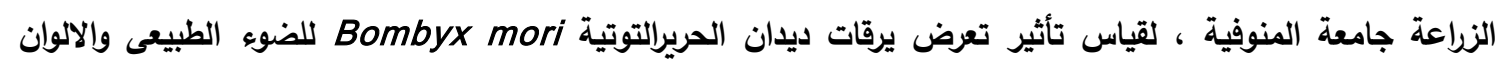

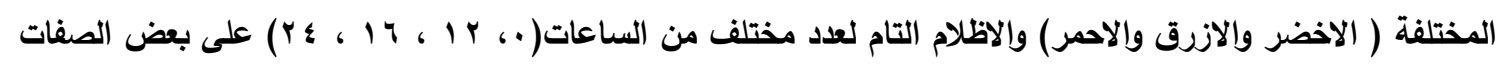
الفسيولوجية .

توضح النتائج التالية القياسات الفسيولوجية في غدة الحريرلليرقات التي تعرضت للمعاملات المختلفة والقياسات التي

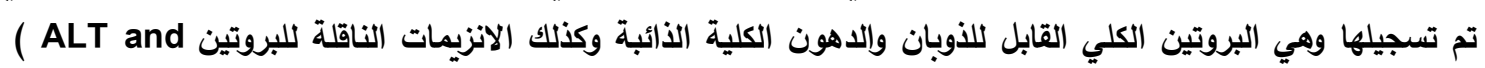

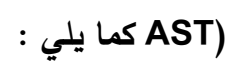

$$
\text { ا }
$$

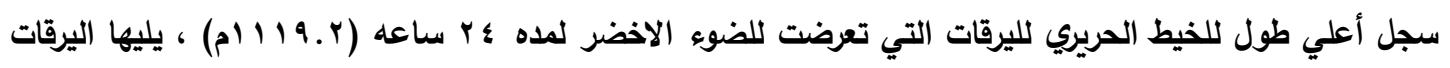

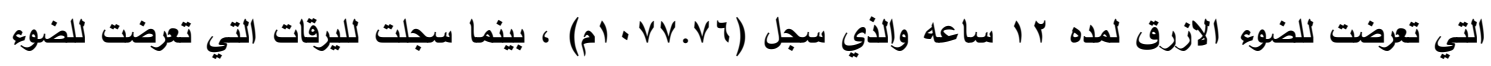

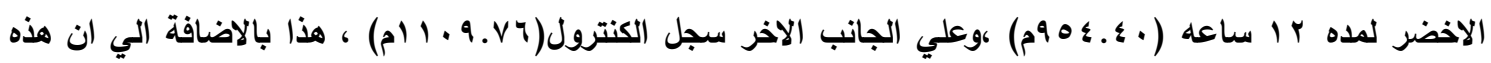
الاضافات المختبرة سبيت أعلي طول خيط حريربالمقارنة مع الكنترول. r - وزن الخيط الحريري(جم) :

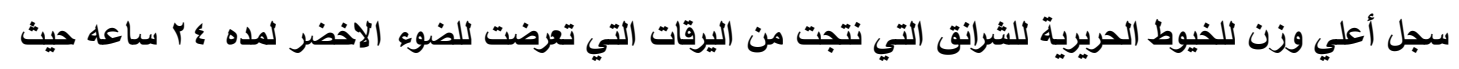

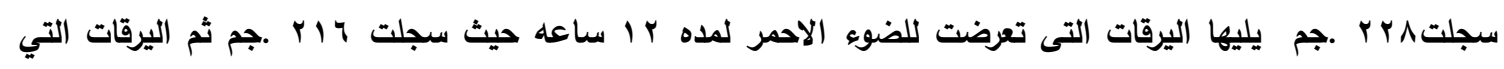

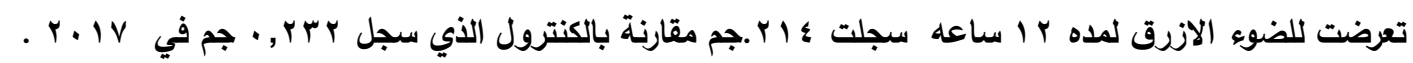

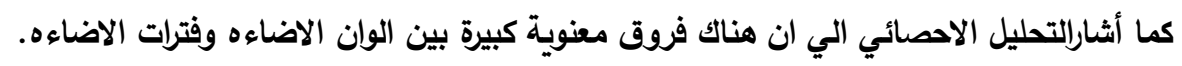

$$
\text { ب - حجم الخيط الحريري (دنير): }
$$

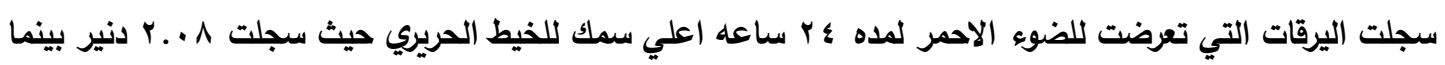

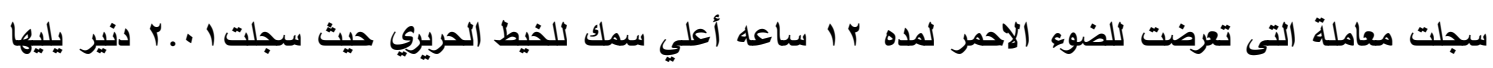

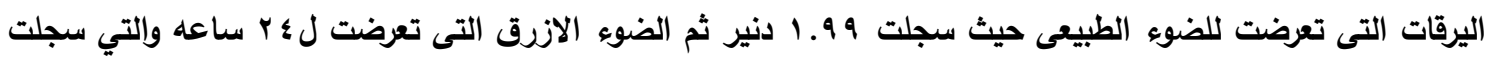

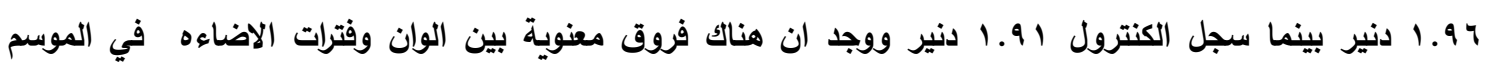

$$
\text { ؛ - البروتين الكلي القابل للذوبان (ملجم/مل) : }
$$

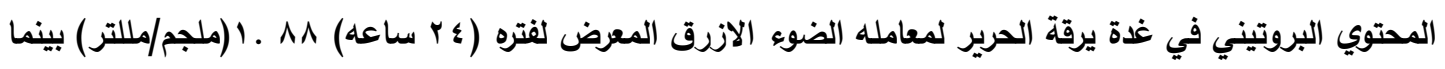

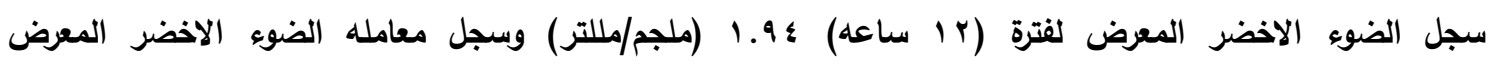




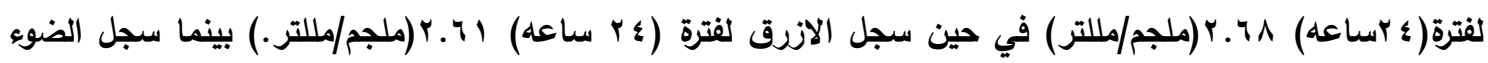

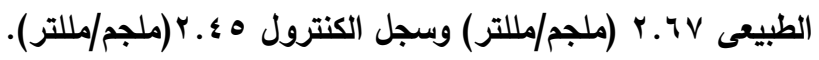
ه - الدهون الكلية (ملجم/مل) :

سجلت الدهون الكلية في غدة يرقة الحريرللضوء الطبيعى 9 با (ملجم/مللتر) وفى الضوه الاحمر المعرض لفترة

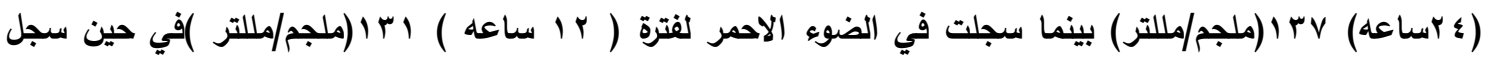

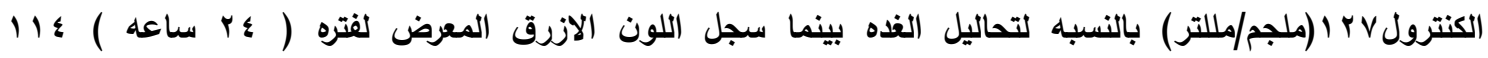

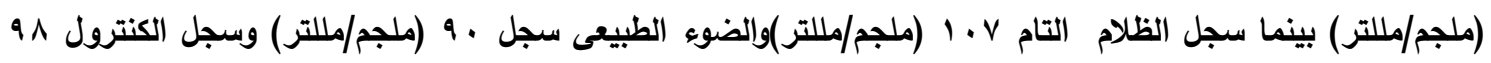
(ملجم/مللتر). צ- الانزيمات الناقلة للبروتين (ALT and AST): : ALT 1-9

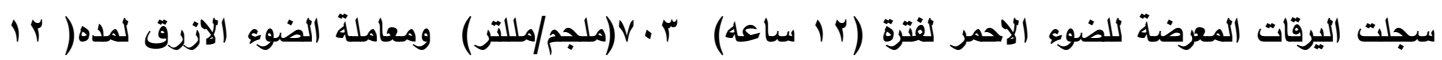

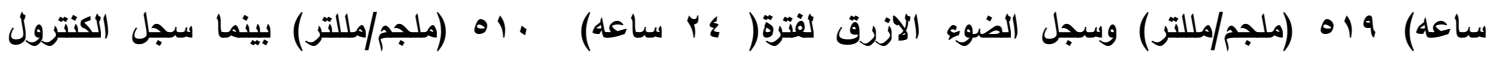

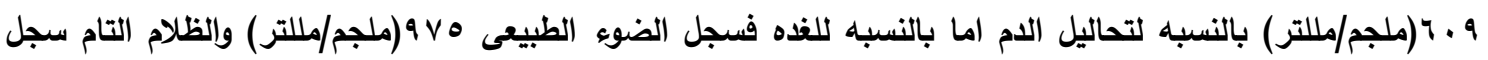

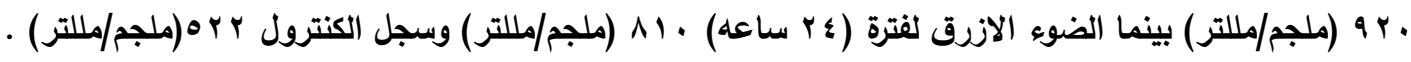
:AST $r-\uparrow$

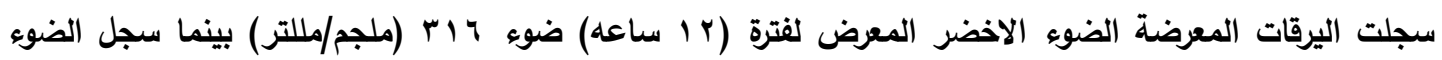

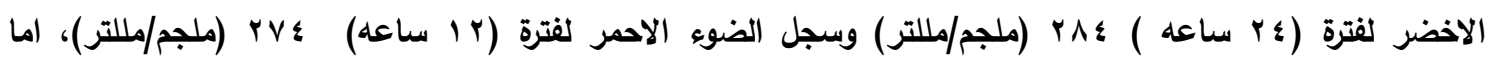

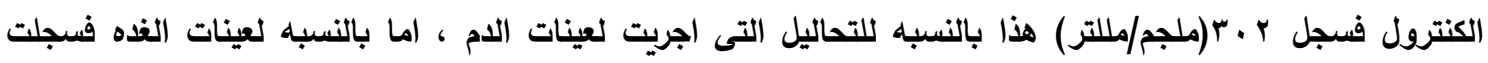

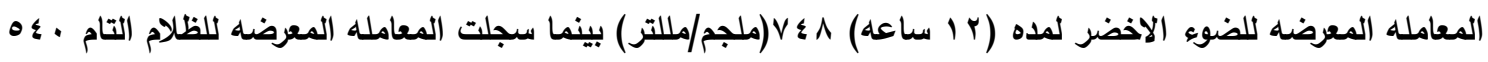

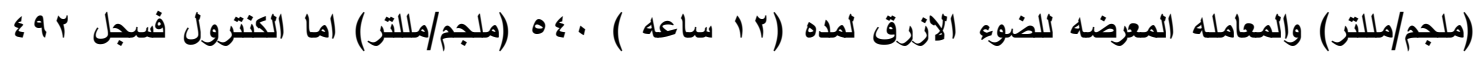


